\title{
The effect of occupational commitment and mobbing on the intention to leave in road transportation during the COVID- 19 pandemic period
}

\author{
COVİD-19 pandemi sürecinde karayolu taşımacılığındaki meslekî \\ bağlılığın ve mobbingin işten ayrılma niyeti üzerindeki etkisi
}

\author{
Gözde Yangınlar1 iD \\ Nurgün Bal2
}

1 Assoc. Prof., İstanbul Ticaret University,
İstanbul, Turkey

gyanginlar@ticaret.edu.tr

ORCID: 0000-0002-3814-2982

2 Asisst. Prof., Beykent University, İstanbul, Turkey,

nurgunbal@beykent.edu.tr

ORCID: 0000-0001-5140-8776

\section{Corresponding Author:}

Gözde Yangınlar,

İstanbul Ticaret University, İstanbul, Turkey,

gyanginlar@ticaret.edu.tr

\section{Submitted: $03 / 05 / 2021$}

Revised: 13/07/2021

Accepted: 28/07/2021

Online Published: 25/09/2021

Citation: Yangınlar, G., \& Bal, N., The effect of occupational commitment and mobbing on the intention to leave in road transportation during the COVID-19 pandemic period, bmij (2021) 9 (3): 835850, doi:

https://doi.org/10.15295/bmij.v9i3.1829

\begin{abstract}
The road transportation sector is an integral part of foreign trade and the locomotive of economic development. The COVID-19 outbreak caused the closure of customs gates for a certain period in addition to a decrease in demand for goods and services and thus profoundly affected the road transport industry. For businesses operating in the road transportation sector, occupational commitment and exposure to mobbing of employees during the pandemic are vital in terms of business performance. This study examines occupational commitment and mobbing on the intention to leave during the COVID-19 pandemic. Although there are many studies in the literature on the effects of the COVID-19 pandemic, there has been no study examining the relationship between these three variables in the road transportation industry. This study is the first empirical study to examine variables such as intention to leave, mobbing, and professional commitment during the pandemic period in Turkey. The research universe consists of 45 logistics companies that provide transportation, customs clearance, storage, insurance, logistics value-added services. The sample consists of businesses engaged in national and international road transport, strengthening the representation ability. As a result of the study, it was determined that mobbing sub-factors did not decrease emotional, occupational commitment, and mobbing increased the intention to leave. Thus, it has been proven that there is a negative relationship between emotional and normative occupational commitment and intention to leave. It is expected that this study will contribute significantly to the businesses and the literature operating in road transportation during the COVID-19 pandemic.
\end{abstract}

Keywords: COVID-19, Road Transportation, Occupational Commitment, Mobbing, Intention to Leave

Jel Codes: L91, M10

Öz

Karayolu taşımacılığı sektörü dış ticaretin ayrılmaz bir parçası ve ekonomik kalkınmanın lokomotifidir. COVID-19 salgını gümrük kapılarının belirli bir süre kapatılmasına, mal ve hizmet taleplerindeki düşüşün yaşanmasına neden olmuş ve karayolu taşımacılık sektörünü derinden etkilemiştir. Karayolu taşımacılık sektöründe faaliyet gösteren işletmeler açısından pandemi sürecinde çalışanların meslekî bağlllıkları ve mobbinge maruz kalma durumları işletme performansı açısından hayati öneme sahiptir. Bu çalışmanın amacı, COVID-19 pandemi sürecinde meslekî bağlllık ve mobbingin işten ayrılma niyeti üzerindeki etkisini incelenmektir. Literatürde COVID-19 pandemisinin etkilerine ilişkin birçok çalışma olmasına rağmen karayolu taşımacılığı sektöründe bu üç değişken arasındaki ilişkiyi inceleyen bir çalışmaya rastlanmamıştır. Bu çalışma, Türkiye'de pandemi döneminde işten ayrılma niyeti, mobbing ve meslekî bağllılı gibi değişkenleri inceleyen ilk ampirik çalışma özellğini taşımaktadır. Araştırmanın evrenini taşıma, gümrükleme, depolama, sigorta, lojistik katma değerli hizmetler sunan 45 lojistik firması oluşturmaktadır. Örneklemin hem ulusal hem de uluslararası karayolu taşımacılığı yapan işletmelerden oluşması temsil kabiliyetini güçlendirmektedir. Araştırma sonucunda, mobbing alt faktörlerinin duygusal meslekî bağlllı̆̆ı azaltmadığı ve mobbingin işten ayrılma niyetini artırdığı belirlenmiştir. Duygusal ve normatif meslekî bağ lılık ile işten ayrılma niyeti arasında negatif bir ilişki olduğu kanıtlanmıştır. Bu çalışmanın COVID19 pandemi döneminde karayolu taşımacılı̆̆ı alanında faaliyet gösteren işletmelere ve literatüre önemli katkılar sağlaması beklenmektedir

Anahtar Kelimeler: COVID-19, Karayolu Taşımacılığı, Meslekî Bağlllık, Mobbing, İşten Ayrilma Niyeti

JEL Kodları: L91, M10 


\section{Introduction}

The COVID-19 epidemic, which originated in China in December, appeared in Turkey in March 2020, has affected the world ever since is a very large-scale crisis that causes global supply chain interruptions. By creating a domino effect in the supply chains, the businesses shut down, the supplier enterprises could not sell their products, and the prospective client could not provide input. All countries faced economic and social crises due to the epidemic that affected the world. The economic crisis has adversely affected countries with intense international trade, and one of the sectors most affected has been the road transportation sector. When the road transport data in 2020 and 2019 are compared, passenger transport decreased by $14.9 \%$ compared to the previous year, while cargo transport increased by $1.99 \%$ (KGM, 2021).

Especially in the COVID-19 pandemic, issues such as occupational commitment, mobbing, and intention to leave have been a subject of interest in business (Said and El-Shafei, 2021). In an increasingly competitive environment with globalization, meeting employees' sensitivity affects their occupational commitment and is vital in reducing their intention to leave (Varol, Karaer and Ortakarpuz and 2017). In recent years, mobbing, which is spreading rapidly in international businesses, advancing insidiously, decreasing the synergy and energy of the business, has been faced. Mobbing is a fundamental organizational problem that causes tension and a conflictual climate and negatively affects the employees' job satisfaction and occupational commitment. The loss of corporate memory and the costs incurred in the organization if employees exposed to mobbing leave their jobs are also remarkable (Erdirençelebi and Filizöz, 2016). During the COVID-19 pandemic, selection and training efforts to find qualified employees along with qualified personnel are reflected as an additional cost to the business. The costs arising in this process can directly affect the productivity and profitability of the business (Abdallaa, Said, Ali, Ali and Chen, 2021).

The purpose of this study is to examine the relationship between exposure to mobbing, occupational commitment levels, and their intention to leave the road transport industry during the COVID-19 pandemic period. Unfortunately, there is no study investigating the highway transport workers' occupational commitment, intention to leave, and mobbing during the COVID-19 pandemic in the literature review. So, the specified gaps in the literature are tried to be fulfilled via this study's contributions as listed below:

1. This study aims to analyse the relationship among occupational commitment levels of highway transport workers, mobbing, and intention to leave. The survey is specially constructed for this study and applied in 45 large and medium-sized logistics enterprises.

2. It reveals the level of mobbing exposure of highway transport workers during the COVID-19 pandemic process.

3. It is to measure which of the occupational commitment factors of highway transport workers is higher during the COVID-19 pandemic.

4. It is to determine intention to leave whether highway transport workers' leave their jobs is high during the COVID-19 pandemic.

5. It is anticipated that this study will significantly contribute to the logistics sector practitioners and the literature.

The study consists of five parts. In the first part, the introduction, in the second part, a literature review was done on-road transportation, mobbing, occupational commitment, and intention to leave during the COVID-19 pandemic period. The method of the research is included in the third part and the findings in the fourth chapter. Finally, in the fifth chapter, results and evaluations are presented.

\section{Literature review}

\section{Road transportation during the COVID-19 process}

Road transportation is defined as the mode of transport that can offer unique solutions to the demands and demands of the consumer, performs the delivery of the products from the exit point to the destination point by vehicles for a certain fee, and is realized with a contract between the carrier and the shipper (Taşkın and Durmaz 2012). The fact that the entrance to the market in road transportation and infrastructure costs are lower than other transport modes facilitate entry to the sector and enables road transport to be more widespread. If the geographical conditions are suitable, the transportation network is quite vast. It has a unique capability as it is the only type of transportation provided from door to door. Also, It is more advantageous to plan trips at any time of the day and provide loading- 
unloading services compared to other transportation modes. Road transportation provides a high degree of flexibility in the time schedules and routes of transport vehicles in passenger and freight transportation (Karacan and Kaya 2011). In addition to the shipment of products of very different volumes.

Although road transportation has many positive aspects, its negative aspects are also remarkable. Affected by weather conditions, high risk of accidents, additional costs incurred in customs procedures, long waiting times reduce transportation efficiency. Besides, high costs and the need for additional equipment pose disadvantages in transporting high tonnage products (Doğan, 2014). In addition to the fact that fixed costs are higher than low variable costs, unit costs are also higher than maritime and rail transportation (Acar and Çakmak, 2013). Also, it is less preferred in the shipment of tiny loads in terms of time and cost factors (Koban and Keser, 2011).

The COVID-19 outbreak in Turkey, which started in March 2020, caused many procurements and road shipment processes problems. In this process, the road transport operation has changed drastically. Logistics enterprises have implemented road transport, storage, distribution, and inventory functions by using technological tools with a few personnel and paying attention to social distance and hygiene rules. Studies have been carried out to determine the contact of infected employees working in the highway operation with other employees, and social severe distancing measures have been taken. No studies have been found in the literature that examines the impact of the COVID-19 outbreak only on the road transportation sector. There are many studies in the literature dealing with the effects of the COVID-19 pandemic within the logistics and supply chain management framework. In the study of Senir (2021), it was stated that quarantine practices and employees who are unable to go to work could cause deterioration in supply; It draws attention to the fact that changes in consumer preferences cause deterioration in demand. Problems were encountered, especially in supplying medical supplies such as respirators, masks, and medicine. There were difficulties in supplying protective equipment such as gloves, masks, hand disinfectants to highway workers.

Nakiboğlu (2020) stated in his study that the COVID-19 outbreak caused limitations in national and international logistics activities, delays in shipments, and increased logistics costs. In their study, Akçac1 and Çınaroğlu (2020) pointed out that as a result of additional controls at international border entries and exits due to the effect of the pandemic, long vehicle queues are formed, and delays in shipment are experienced. These delays also lead to increases in freight prices. Furthermore, according to Genç and Kaya (2021), many new regulations related to international trade and transportation implemented with the COVID-19 epidemic (such as the transition to the appointment system in customs procedures, change of ATR processes, restrictions on some products in international trade, and the obligation of 14day quarantine for drivers ...) They discussed this in detail. Besides, they argue that the inability to deliver on time negatively affects international logistics performance; container supply time reaches 23 weeks, and deliveries are made at least 2-3 days late.

In their study, Liu, Liang, Bao, Qin, Lim (2020) explained that the COVID-19 outbreak in China disrupted the logistics distribution networks of enterprises and significant reductions in logistics demands and transport capacities. It is stated that logistics centres are vital in delivering urgent materials as soon as possible in this epidemic. In his study, Mogaji (2020) concluded that the COVID-19 outbreak in Nigeria caused an increase in transportation costs, a decrease in operational efficiency, and a lack of transportation infrastructure. Loske (2020) mentioned that the change in the purchasing behaviour of consumers due to the restrictions in Germany affects the transport capacity dynamics, and the demand for the transportation of uncooked food products has increased. Saladie, Bustamante, Gutierrez (2020) found that with the COVID-19 outbreak, traffic accidents in the Spanish province of Tarragona decreased by about $74 \%$. Akbal (2020) emphasizes the need to establish a flexible supply chain against demand fluctuations to prevent the bullwhip effect in the COVID-19 pandemic. Furthermore, it emphasizes the importance of practical information sharing with each member in the supply chain over the information network. Karlı and Tanyaş (2020) determined that the importance of information in supply chain management increased even more during the pandemic process, and those strategies developed to minimize supply chain management risks should be managed proactively.

During epidemic periods, there are usually difficulties in material supply, decreased efficiency in operational activities, and price fluctuations (Ivanov, 2020). It is seen that similar situations are experienced in this epidemic. Due to the COVID-19 crisis, it is predicted that approximately 25 million people will lose their jobs globally, and millions will be unemployed, so the impact of COVID-19 on global working life will be both very deep and extensive (ILO, 2020). Also, the widespread use of elogistics activities during the pandemic has created new bottlenecks for logistics service providers. Sudden unexpected developments in demand and supply revealed the necessity for logistics enterprises 
to have a more flexible structure. The highway transport workers must work in coordination with the business personnel involved in supply chain management.

\section{Mobbing}

Mobbing is defined as the systematic, specific, frequently applied harmful behaviours and pressures to subordinates of superiors, superiors or subordinates, or colleagues with the same status within the organization (Vandekerckhove and Commers, 2003). This concept is a complex and multidimensional issue frequently encountered in workplaces but often cannot be explained by the person for personal reasons, avoided and sometimes ignored, and has severe effects on employees' physical and psychological conditions (Kudielka 2004).

The feature that distinguishes mobbing from the ongoing conflict between two workers is a type of behaviour and conflict that can cause psychological and physiological damage to the individual in its systematic and long-term development and consequences (Browne and Smith, 2008). Mobbing is a process that develops in various stages and can turn into more disturbing behaviours over time. These behaviours may be persistent, aggressive, insulting, or abusing their power, causing the other person to feel threatened, humiliated, and confused (Clarke, 2002). It starts unnoticed but progresses so quickly that irreversible points can be reached (Davenport, Schwartz and Elliott, 2003). The loss of those exposed to mobbing occurs not only socially but also economically. Victims may choose to accept mobbing, not complain, and avoid conflict, or they may intend to quit and find it more appropriate to report this situation to senior management (Altunay, Oral and Yalçınkaya, 2014). Those exposed to mobbing are not only affected, but they also think that other colleagues may be exposed to such negative behaviours. To not be a victim and survive within the organization, mobbing employees leads to unethical behaviours. As a result, employees lose their trust in each other and the organization and seek new jobs. Vartia (2001) proved that factors such as the structure of the organization, the characteristics of the job, and leadership styles are related to mobbing and that the victims of mobbing experience discomfort such as job dissatisfaction, depression, and absenteeism. In his study, Salin (2001) stated that those at the lower hierarchy levels are more likely to be exposed to mobbing.

\section{Occupational commitment}

Occupation is an influential factor in the individual's self-realization and self-definition within the social structure, and it is defined as the activities that people maintain based on the knowledge and skills gained through a specific education to earn their lives (Elchardus and Smiths, 2008). This concept effectively makes the individual's perception of his profession bring behavioural results and make the individual visible in society (Teng, 2008).

Occupation commitment is expressed as employees' psychological relationships with their professions and emotional reactions (Allen and Meyer, 1990). In this context, it is observed that employees with high professional commitment make efforts to develop their skills and qualifications, spend energy to develop their careers, and feel a sense of gratitude to their organizations. Changes in working conditions obscure employees' career development and cause them to develop a negative attitude towards their organization (Morrow, 1993). Occupation commitment is a conceptual structure consisting of emotional, normative, and continuity dimensions (Meyer, Allen and Smith, 1993). Employees feel that investing in their profession is a more rational approach to cope with environmental and organizational uncertainty. In this context, they prefer to be attached to their profession rather than to their organization (Blau, 2003). Factors such as leadership characteristics within the organization, wage level, and working conditions may be effective in the occupation commitment of employees and their decision to leave (Cohen, 2000).

\section{The intention to leave}

The intention to leave the job is described as the active and destructive actions taken by the employees when they are not satisfied with the working conditions (Rusbelt, Farrell, Rogers and Mainous, 1988). This concept is also expressed as individuals' desire to leave their current jobs or professions to seek a new job or profession (Meyer, Stanley, Herscovitch and Topolnytsky, (2002). The employee's desire to consciously plan and realize the departure from his organization and the continuity of this request effectively realises the intention to leave (Allen, Weeks and Moffitt, 2005; Cho, Johanson and Guchait, 2009). The cognitive and behavioural stages of the intention to leave function as the employee's decision to leave the organization (Lagerlund, Sharp, Lindqvist, Runesdotter and Tishelman, 2015).

The intention to leave is classified into three groups: exogenous, personal, and work-related factors. External factors include employees' perceptions, unemployment rates, and resumption rates; personal factors include age, gender, years of employment, education, marital status. Work-related factors are 
wage, job performance, job description, job satisfaction, routine work, promotion opportunities (Tuna and Yeşiltaş, 2014). Factors affecting employees' intention to leave their jobs are also stated as "environmental factors, organizational culture and values, relations with colleagues, job/role demands and expectations, and career development opportunities" (Takase, Maude and Manias, 2005). Weisberg and Kirschenbaum (1991) stated in their study that the intention to leave decreased as the age and the duration of the experience increased, and the higher the education level and professional level, the higher the intention to quit. Cotton and Tuttle (1989) found a negative relationship between intention to leave and income level. Griffeth, Hom and Gaertner, (2000) argued that lower-income employees intend to quit more. Employees who see low wage levels can easily be divided into organization memberships. In their studies, Kaur and Mohindru (2013) stated that besides the awareness of wage, satisfaction with the management style, organizational commitment, and procedural fairness also affect the intention to leave.

The intention to leave is a preliminary indication of absenteeism and can bring substantial costs to businesses. Besides, when an employee leaves his job, the social interaction and communication between other employees in the organization may deteriorate, the emergence of anxiety and tension, and adaptation problems with the new person is observed (Kanten, 2014). In addition to negatively affecting the quality of products and services, the departure of a qualified workforce may decrease the enterprise's competitive advantage (Hsiao, Auld and Ma, 2015). It is observed that employees with low job satisfaction have a high intention to leave, but if the employee has limited job opportunities, inadequate skills, and the labour market in which they supply labour is in a bad situation, they may prefer to stay in their current job, even if their job satisfaction is shallow. (Feldman and Arnold 1983).

\section{Method of research}

\section{The purpose, importance and model of the research}

A model has been developed within the framework of the purpose of the research, and it is given in Figure 1.

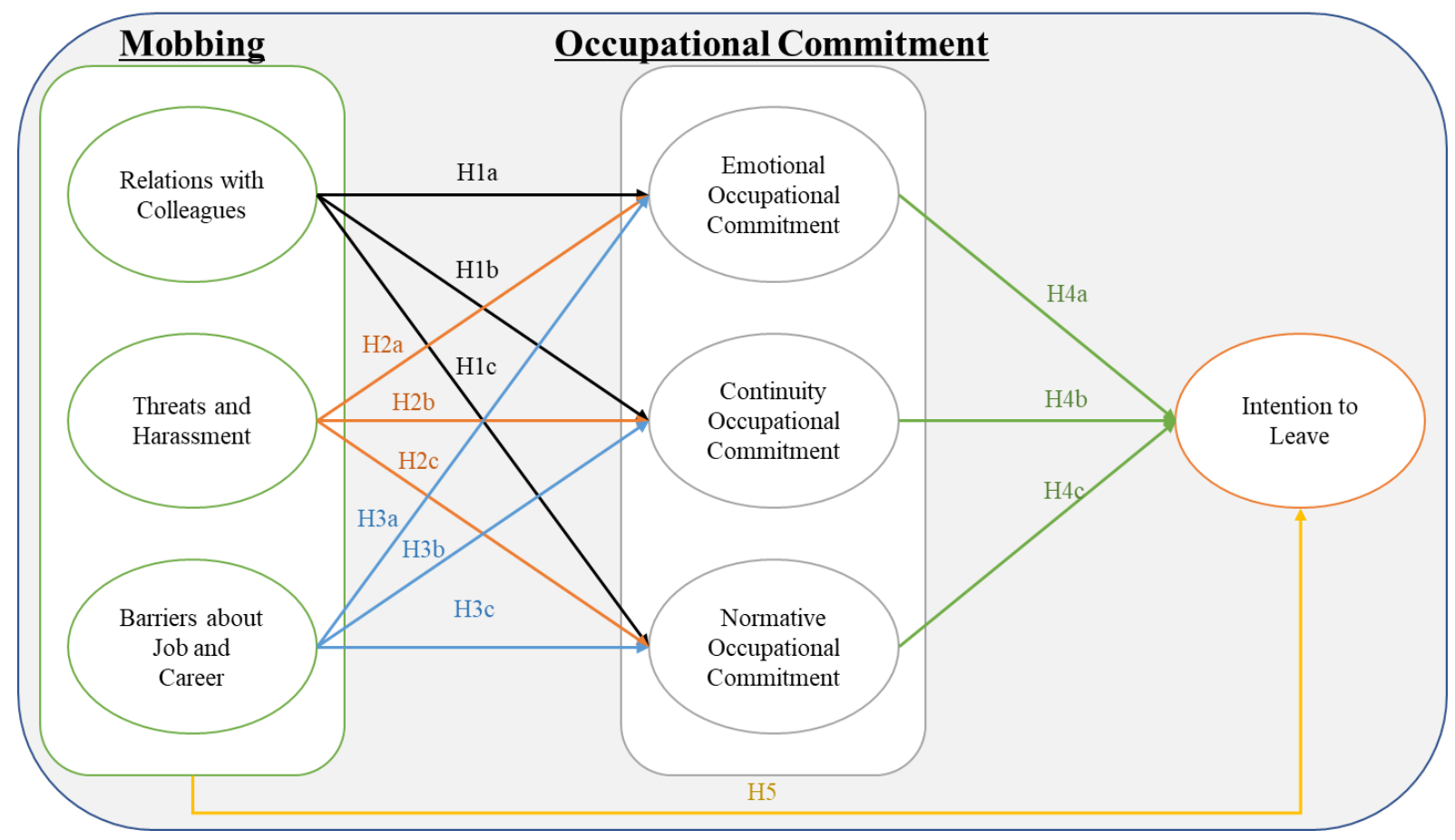

Figure 1: Research Model

The relational scanning model, one of the scanning models, was used in the research. A relational screening model is a research model that aims to determine the existence and degree of change between two or more variables (Karasar, 1998). Uştu and Tümkaya (2017) state that the variable affecting emotional commitment the most is commitment. They found out that the variable that affected the continuity and normative occupational commitment the most was the intention to leave. Erdirençelebi and Filizöz (2016) evaluate a positive relationship between mobbing sub-dimensions and the intention to leave. Arıkan Saltık, Avcı and Kaya, (2016) determine that the perception of the social status of the 
profession and individual-profession harmony have a significant and positive effect on occupational commitment, while they explain that high occupational commitment reduces the intention to leave.

Meyer, Allen and Smith (1993) declare that when emotional attachment to the profession is high, the tendency to stay in the profession. Carson, Carson, Philips and Roe, (1996) argue that individuals affiliated with their profession can maintain their membership even if they are not affiliated with their organization, considering the scarcity of job alternatives or the cost of leaving the profession. Wildes (2004) states a significant relationship between an individual's perception of his profession and continuing the profession. The probability of the employee leaving the organization at any time in the future depends on the individual's behaviour, the underlying goal of the behaviour, and when the behaviour is activated (Hughes et al., 2010). It is predicted that the intention to leave will develop in enterprises where the level of organizational trust and organizational commitment is low (Huff and Kelley, 2003). In addition to the loss of organizational knowledge, culture, talent, and workforce, this situation also causes negative recruiting consequences such as orientation and training costs (Harvey, Harris and Martinko, 2008). Cunninghan and MacGregor (2000) conclude that organizational trust directly affects job satisfaction and the intention to quit. If employees do not see the possible future successes of the organization and themselves as sufficient, they intend to quit. The employee is dependent on his profession but may not be affiliated with the organization; if the organization does not satisfy the professional needs of the individual, the intention to leave the organization increases (Goulet and Singh, 2002).

In line with the purpose of the study, the model of the research was designed as follows.

Hypothesis 1a. Relations with colleagues have a negative influence on emotional, occupational commitment.

Hypothesis $1 \mathrm{~b}$. Relations with colleagues have a negative influence on occupational continuity commitment.

Hypothesis 1c. Relations with colleagues have a negative influence on normative occupational commitment.

Hypothesis 2a. Threats and harassment have a negative influence on emotional, occupational commitment.

Hypothesis $2 \mathrm{~b}$. Threats and harassment have a negative influence on occupational continuity commitment.

Hypothesis 2c. Threats and harassment have a negative influence on normative occupational commitment.

Hypothesis 3a. Barriers to job and career have a negative influence on emotional, occupational commitment.

Hypothesis $3 \mathrm{~b}$. Barriers to job and career have a negative influence on occupational continuity commitment.

Hypothesis 3c. Barriers to job and career have a negative influence on normative occupational commitment.

Hypothesis 4a. Emotional, occupational commitment careers have a negative influence on intention to leave.

Hypothesis $4 \mathrm{~b}$. Continuity occupational commitment has a negative influence on the intention to leave.

Hypothesis 4c. Normative occupational commitment has a negative influence on the intention to leave.

Hypothesis 5. Mobbing has a positive influence on the intention to leave.

\section{Sampling and data collection}

The sample of the study consists of employees of logistics companies operating in road transport in Istanbul. Therefore, simple random sampling to collect data method was preferred. During the data collection phase, contacts were made with employees in the road import, road export, road sales, and marketing departments of 45 large and medium-sized logistics enterprises. Firstly, a pilot survey was conducted with 50 highway transport workers to test that the questionnaire applied in the study was valid and suitable for the study. In the light of the information obtained from the preliminary study, the questionnaire was given its final form. The study's sample size is 186 at the $95 \%$ confidence level and $5 \%$ tolerance level for 360 highway transport workers. Seven hundred questionnaires were shared 
online between May 2020 and March 2021. A total of 275 questionnaires were returned. Thirty-one of them were not taken into account because they were filled incompletely and incorrectly. The remaining 244 questionnaires formed the data set of the study. This study was conducted online to 45 logistics companies due to time, cost, and risk of contamination during the COVID-19 pandemic process. Another constraint is the refusal of the highway transport workers to survey by declaring that they do not have time to conduct a survey.

\section{Analysis of research data}

The evaluation of the research data was made with the "SPSS" statistical package program. A 5-point Likert scale was used in both scales applied in the study. According to the scoring used in the scale, the items are graded from 1 to 5. The responses of "1: I do not agree at all", "2: I do not agree", "3: I am undecided", "4: I agree", "5: I completely agree" are selected by the participants. Considering Baysal and Paksoy (1999) work, it was decided to use Meyer's Three-dimensional Occupational Commitment Scale, Allen and Smith (1993). The mobbing scale is from the studies of Laleoğlu and Özmete (2013), and the intention to leave scale is from Gül, Oktay and Gökçe, (2008) adapted.

\section{Findings}

Within the scope of the findings, the demographic characteristics of the participants are revealed. The reliability and factor analysis of the scales used in the study are examined, and finally, the findings obtained as a result of the regression analysis and hypothesis tests are shown.

The distribution of road transportation employees participating in the study according to the variables of gender, marital status, age, education status is shown in Table 1.

Table 1: Demographic Findings

\begin{tabular}{|c|c|c|c|c|c|}
\hline \multicolumn{6}{|c|}{ Frequency Distributions of Demographic Variables } \\
\hline Gender & Frequency & $\%$ & Education status & Frequency & $\%$ \\
\hline Female & 119 & 48.8 & High school & 14 & 5.7 \\
\hline Male & 125 & 51.2 & Associate degree & 37 & 15.1 \\
\hline Total & 244 & 100.0 & $\begin{array}{l}\text { Undergraduate } \\
\text { education }\end{array}$ & 139 & 57.0 \\
\hline Age & Frequency & $\%$ & Post graduate & 54 & 22.1 \\
\hline Under 20 & 18 & 7.4 & Total & 244 & 100.0 \\
\hline $20-29$ & 107 & 43.9 & Marital status & Frequency & $\%$ \\
\hline $30-39$ & 69 & 28.3 & Married & 105 & 43.0 \\
\hline $40-49$ & 34 & 13.9 & Single & 139 & 57.0 \\
\hline 50 and above & 16 & 6.6 & Total & 244 & 100.0 \\
\hline Total & 244 & 100.0 & Working time & Frequency & $\%$ \\
\hline Income Level & Frequency & $\%$ & Less than 1 year & 18 & 7.4 \\
\hline $2500 €$ and below & 32 & 13.1 & $1-3$ years & 50 & 20.5 \\
\hline 2501-3500€ & 67 & 27,5 & 4-6 years & 37 & 15.2 \\
\hline 3501- $4500 €$ & 57 & 23.4 & $7-9$ years & 59 & 24.2 \\
\hline $4501-5500 €$ & 49 & 20,1 & 10 years and above & 80 & 32.8 \\
\hline $5501-6500 €$ & 39 & 16.0 & Total & 244 & 100.0 \\
\hline Total & 244 & 100.0 & & & \\
\hline
\end{tabular}

According to Table 1, it was determined that $43.9 \%$ of the participants were between the ages of 20-29. When the gender groups of the participants are examined, it is seen that $51.2 \%$ of them are male, and $48.8 \%$ are female. Therefore, it was found that the ratio of males to females in the sample was close to each other. Furthermore, it was determined that most of the participants were undergraduate $(57.0 \%)$, and their education level was high. The highway transport workers with more than ten years of work make up $32.8 \%$ of the sample.

The questionnaire used in the field research was created by making use of the studies in the literature. The questions received were updated in line with the sample, and a reliability study was conducted for the questionnaires. In addition, Cronbach's Alpha analysis was applied to examine the reliability of the scales used. 
Table 2. Reliability Analysis

\begin{tabular}{|c|c|c|c|c|}
\hline & Cronbach's Alpha & $\bar{x}$ & Std. Error & Std. Deviation \\
\hline Intention to leave scale & 0.621 & 1.8770 & 0.04122 & 0.64392 \\
\hline \multicolumn{5}{|c|}{ Mobbing Scale } \\
\hline Relations with colleagues & 0.903 & 1.5123 & 0.03589 & 0.56060 \\
\hline Threats and harassment & 0.726 & 1.2787 & 0,02195 & 0.34288 \\
\hline Barriers about job and career & 0.910 & 1.6506 & 0.04602 & 0.71891 \\
\hline \multicolumn{5}{|c|}{ Occupational Commitment Scale } \\
\hline $\begin{array}{c}\text { Emotional occupational } \\
\text { commitment }\end{array}$ & 0.775 & 2.0605 & 0.05300 & 0.82787 \\
\hline $\begin{array}{l}\text { Continuity occupational } \\
\text { commitment }\end{array}$ & 0.875 & 3.1770 & 0.06922 & 1.08129 \\
\hline $\begin{array}{c}\text { Normative occupational } \\
\text { commitment }\end{array}$ & 0.726 & 3.1342 & 0.05661 & 0.88434 \\
\hline
\end{tabular}

Data on the levels of occupational commitment, mobbing, intention to leave of the highway transport workers included in the sample are given in Table 2. As a result of the analysis, in the occupational commitment scale, which is a 5-point Likert type scale; Emotional commitment of the highway transport workers expressed with four items is low $(\bar{x}=2.06)$, continuity attachment expressed with five items is moderate $(\bar{x}=3.17)$, and normative commitment expressed with four items is moderate $(\bar{x}=3.13)$. According to the findings, while continuity commitment scores of the highway transport workers have the highest average, their emotional commitment scores have the lowest average. On the mobbing scale, it was determined that the highway transport workers had low levels of relations with colleagues 5item, threat and harassment 8 -item, barriers about job and career expressed with 11 items. Furthermore, it is observed that the mean of the intention to leave the scale, which consists of 3 questions, is also low for the highway transport workers. Considering the results of the reliability analysis, relations with colleagues $(\alpha=0.903)$, threats and harassment $(\alpha=0.726)$, and barriers about job and career $(\alpha=0.910)$ scales are reliable determined. According to the result of the reliability analysis made with all the questionnaire questions, the reliability coefficient was determined as $\alpha=0.795$, and the scale was found to be reasonably reliable. Principal component analysis with varimax rotation is employed to clarify the dimensions of occupational commitment and mobbing on the intention to leave in the road transportation sector. 
Table 3: Factor Analysis of Mobbing Scale

\begin{tabular}{|c|c|c|c|}
\hline \multirow[b]{2}{*}{ Mobbing Scale } & \multicolumn{3}{|c|}{ Factor Loadings } \\
\hline & $\begin{array}{l}\text { Relations with } \\
\text { colleagues }\end{array}$ & $\begin{array}{l}\text { Threats and } \\
\text { harassment }\end{array}$ & $\begin{array}{l}\text { Barriers about job } \\
\text { and career }\end{array}$ \\
\hline I feel that I become the target of disrespectful behavior. & 0.844 & & \\
\hline $\begin{array}{l}\text { I think that I become the target of humiliating } \\
\text { remarks. }\end{array}$ & 0.836 & & \\
\hline $\begin{array}{l}\text { I think I am scapegoated by my highway transport co- } \\
\text { workers. }\end{array}$ & 0.800 & & \\
\hline $\begin{array}{l}\text { My highway transport co-workers pretext to rebuke me. } \\
\text { I think no one listens to me. }\end{array}$ & 0.786 & & \\
\hline $\begin{array}{l}\text { I think my highway transport co-workers are boycotting } \\
\text { me. }\end{array}$ & 0.709 & & \\
\hline $\begin{array}{l}\text { My highway transport co-workers speak to me in } \\
\text { aggressive tones. }\end{array}$ & 0.701 & & \\
\hline $\begin{array}{l}\text { I get the impression of being monitored by my highway } \\
\text { transport co-workers. }\end{array}$ & 0.683 & & \\
\hline I feel a hostile climate around me. & 0.670 & & \\
\hline $\begin{array}{l}\text { My highway transport co-workers behave that as If I don't } \\
\text { exist. }\end{array}$ & 0.660 & & \\
\hline My highway transport co-workers speak behind my back. & 0.600 & & \\
\hline I think I have been subjected to sexual harassment. & & 0.731 & \\
\hline $\begin{array}{l}\text { I receive written threats from my highway transport co- } \\
\text { workers. }\end{array}$ & & 0.702 & \\
\hline $\begin{array}{l}\text { My highway transport co-workers make fun of for my } \\
\text { appearance. }\end{array}$ & & 0.700 & \\
\hline I am exposed to vulgar jokes of sexual content. & & 0.682 & \\
\hline $\begin{array}{l}\text { My highway transport co-workers damage my personal } \\
\text { possessions. }\end{array}$ & & 0.644 & \\
\hline $\begin{array}{l}\text { I consider that I am assigned to job duties. below the level } \\
\text { of those for which I was hired. }\end{array}$ & & & 0.902 \\
\hline I am assigned to deskilled tasks. & & & 0.892 \\
\hline I am asked to perform meaningless tasks. & & & 0.873 \\
\hline $\begin{array}{l}\text { Jobs duties are assigned to me that are not within my } \\
\text { competence. }\end{array}$ & & & 0.872 \\
\hline $\begin{array}{l}\text { I think that my career advancement was prevented by the } \\
\text { management. }\end{array}$ & & & 0.730 \\
\hline $\begin{array}{l}\text { I consider that I am excluded from meetings and official } \\
\text { gatherings. }\end{array}$ & & & 0.696 \\
\hline $\begin{array}{l}\text { I think that my career advancement was deliberately } \\
\text { hampered. }\end{array}$ & & & 0.657 \\
\hline $\begin{array}{l}\text { The essential work instruments are removed without } \\
\text { warning me. }\end{array}$ & & & 0.605 \\
\hline
\end{tabular}

Propositions with factor loadings of 0.80 and above are at a perfect level, factor loadings. It is seen that the propositions between 0.70 and 0.80 are at a reasonable level. When the Barlett Sphericity test is examined, it is seen that a highly significant result was obtained $(p=0.000)$.

Table 4: Factor Analysis of Occupational Commitment Scale

\begin{tabular}{|c|c|c|c|}
\hline \multirow[b]{2}{*}{ Occupational Commitment Scale } & \multicolumn{3}{|c|}{ Factor Loadings } \\
\hline & $\begin{array}{l}\text { Emotional } \\
\text { Occupational } \\
\text { Commitment }\end{array}$ & $\begin{array}{l}\text { Continuity } \\
\text { Occupational } \\
\text { Commitment }\end{array}$ & $\begin{array}{l}\text { Normative } \\
\text { Occupational } \\
\text { Commitment }\end{array}$ \\
\hline I cannot identify myself with this profession. & 0.861 & & \\
\hline I don't like being a highway transport workers. & 0.850 & & \\
\hline I regret that I entered this profession. & 0.750 & & \\
\hline I consider that this job is an exciting. & 0.621 & & \\
\hline It would cost me dearly to change my profession right now. & & 0.865 & \\
\hline If I change my profession, my life will distrupt. & & 0.864 & \\
\hline It will be very difficult for me to change my profession right now. & & 0.848 & \\
\hline I've given too much to consider changing this profession now. & & 0.774 & \\
\hline $\begin{array}{l}\text { Currently, I have to personally endure significant sacrifices in } \\
\text { order to change my profession. }\end{array}$ & & 0.734 & \\
\hline $\begin{array}{l}\text { Due to my loyalty to my profession, I continue to do this } \\
\text { profession. }\end{array}$ & & & 0.876 \\
\hline If I leave this profession, I will feel guilty. & & & 0.762 \\
\hline $\begin{array}{l}\text { I don't think I have the right to leave this profession, even if it give } \\
\text { me an advantage. }\end{array}$ & & & 0.660 \\
\hline $\begin{array}{l}\text { I consider continuing this profession as a responsibility that I } \\
\text { must fulfill. }\end{array}$ & & & 0.659 \\
\hline
\end{tabular}


According to explanatory factor analysis, it is seen that the factor loads of intention to leave are between 0.719 and 0.848 and are at a reasonable level. If the correlation coefficient is between 0 and \pm 0.3 , the strength of the relationship is low. If the coefficient is between \pm 0.3 and \pm 0.7 , the strength of the relationship is medium, and if the coefficient is between \pm 0.7 and \pm 1 , the strength of the relationship is high (Saruhan and Özdemirci, 2016). As a result of the correlation analysis, it was determined that the strength of the relationship between the variables was medium.

Table 5: Regression Analysis Between Mobbing and Emotional Occupational Commitment

Coefficients $^{\mathrm{a}}$

\begin{tabular}{|c|c|c|c|c|c|}
\hline \multirow[t]{2}{*}{ Model } & \multicolumn{2}{|c|}{ Unstandardized Coefficients } & $\begin{array}{c}\text { Standardized } \\
\text { Coefficients }\end{array}$ & \multirow[t]{2}{*}{$t$} & \multirow[t]{2}{*}{ Sig. } \\
\hline & $\beta$ & Std. Error & Beta & & \\
\hline (Constant) & 1.725 & 0.212 & & 8.131 & 0.000 \\
\hline Relations with colleagues & 0.097 & 0.131 & 0.065 & 0.738 & 0.462 \\
\hline Threats and harassment & 0.266 & 0.185 & 0.110 & 1.436 & 0.152 \\
\hline Barriers about job and career & -0.091 & 0.091 & -0.079 & -1.002 & 0.317 \\
\hline
\end{tabular}

R:0.135a R2:0.018 F:1.494 a. Dependent Variable: Emotional occupational commitment.

According to the results in Table 5, it was determined that the relationship between mobbing and emotional, occupational commitment levels was not statistically significant in the multiple linear regression model $(\mathrm{F}=1.494 ; \mathrm{p}<0.001)$. The emotional, occupational commitment of the highway transport workers is not affected negatively when they are exposed to mobbing. It is revealed that a one-unit increase in the mobbing level that the employees are exposed to leads to a $13 \%$ decrease in their emotional, occupational commitment.

Table 6: Regression Analysis Between Mobbing and Continuity Occupational Commitment

Coefficients ${ }^{\mathrm{a}}$

\begin{tabular}{|c|c|c|c|c|c|}
\hline \multirow[t]{2}{*}{ Model } & \multicolumn{2}{|c|}{ Unstandardized Coefficients } & $\begin{array}{l}\text { Standardized } \\
\text { Coefficients }\end{array}$ & \multirow[t]{2}{*}{$\mathrm{t}$} & \multirow[t]{2}{*}{ Sig. } \\
\hline & $\beta$ & Std. Error & Beta & & \\
\hline (Constant) & 3.087 & 0.274 & & 11.278 & 0.000 \\
\hline Relations with colleagues & -0.306 & 0.169 & -0.159 & -1.813 & 0.071 \\
\hline Threats and harassment & 0.611 & 0.239 & 0.194 & 2.553 & 0.011 \\
\hline Barriers about job and career & -0.138 & 0.118 & -0.092 & -1.172 & 0.242 \\
\hline
\end{tabular}

$\mathrm{R}: 0.204 \mathrm{a} \quad \mathrm{R}^{2}: 0.042 \quad$ F: $3.480 \quad$ a. Dependent Variable: Continuity occupational commitment.

According to the analysis in Table 6, mobbing sub-factors and $t$ values calculated for occupational continuity commitment explain the analysis significantly. The calculated $F$ value $(F=3.480)$ shows that mobbing significantly explains the continuity of occupational commitment. Colleagues (p: 0.07), barriers about job and career $(p=0.242)$, among the mobbing sub-factors, were found not negatively to affect occupational continuity commitment. It was determined that only threats and harassment $(p=0.01)$ among the mobbing sub-factors negatively affected the occupational continuity commitment. Therefore, the H2b hypothesis was supported.

When the results in Table 7 are examined, it is seen that the regression model established is valid at a significance level of 0.001 ( $F$ value $=11.097)$. Relations with colleagues $(p=0.014)$, threats and harassment $(p=0.028)$, barriers about job and career $(p=0.000)$ have been found to affect the normative occupational commitment negatively. In the light of this information; It was concluded that the H1c, $\mathrm{H} 2 \mathrm{c}$, and $\mathrm{H} 3 \mathrm{c}$ hypotheses were supported. When the analysis results for each explanatory variable are examined, it is seen that relations with colleagues have the most significant effect on the normative occupational commitment variable $(\beta=0.328)$. 
Table 7: Regression Analysis Between Mobbing and Normative Occupational Commitment Coefficients ${ }^{\mathrm{a}}$

\begin{tabular}{|c|c|c|c|c|c|}
\hline \multirow[t]{2}{*}{ Model } & \multicolumn{2}{|c|}{ Unstandardized Coefficients } & $\begin{array}{c}\text { Standardized } \\
\text { Coefficients }\end{array}$ & \multirow[t]{2}{*}{$\mathrm{t}$} & \multirow[t]{2}{*}{ Sig. } \\
\hline & $\beta$ & Std. Error & Beta & & \\
\hline (Constant) & 3.921 & 0.214 & & 18.294 & 0.000 \\
\hline Relations with colleagues & 0.328 & 0.132 & 0.208 & 2.480 & 0.014 \\
\hline Threats and harassment & -0.413 & 0.187 & -0.160 & -2.207 & 0.028 \\
\hline Barriers about job and career & -0.457 & 0.092 & -0.372 & -4.962 & 0.000 \\
\hline
\end{tabular}

R: $0.349 a \quad R^{2: 0.122} \quad F: 11.097 \quad$ a.Dependent Variable: Normative occupational commitment.

Table 8: Regression Analysis Between Occupational Commitment and Intention to Leave Coefficients $^{\mathrm{a}}$

\begin{tabular}{|c|c|c|c|c|c|}
\hline \multirow[t]{2}{*}{ Model } & \multicolumn{2}{|c|}{ Unstandardized Coefficients } & \multirow{2}{*}{$\begin{array}{c}\begin{array}{c}\text { Standardized } \\
\text { Coefficients }\end{array} \\
\text { Beta }\end{array}$} & \multirow[t]{2}{*}{$\mathrm{t}$} & \multirow[t]{2}{*}{ Sig. } \\
\hline & $\beta$ & Std. Error & & & \\
\hline (Constant) & 3.079 & 0.231 & & 13.326 & 0.000 \\
\hline Emotional occupational commitment & -0.162 & 0.051 & -0.208 & -3.199 & 0.002 \\
\hline Continuity occupational commitment & 0.065 & 0.038 & 0.110 & 1.731 & 0.085 \\
\hline Normative occupational commitment & -0.343 & 0.050 & -0.471 & -6.893 & 0.000 \\
\hline
\end{tabular}
R: $0.377 \mathrm{a} \quad \mathrm{R}^{2:}: 0.167 \quad \mathrm{~F}: 16.002 \quad$ a. Dependent Variable: Intention to leave.

According to Table 8, it is seen that emotional and normative occupational commitment in the road transportation sector positively affects the intention to leave. $16 \%$ of the variance in intention to leave is due to professional commitment. In line with this information; It has been determined that $\mathrm{H} 4 \mathrm{a}$ and $\mathrm{H} 4 \mathrm{c}$ are supported.

Table 9: Regression Analysis Between Mobbing and Intention to Leave

Coefficients ${ }^{\mathrm{a}}$

\begin{tabular}{|c|c|c|c|c|c|}
\hline \multirow[t]{2}{*}{ Model } & \multicolumn{2}{|c|}{ Unstandardized Coefficients } & $\begin{array}{c}\text { Standardized } \\
\text { Coefficients }\end{array}$ & \multirow[t]{2}{*}{$\mathrm{t}$} & \multirow[t]{2}{*}{ Sig. } \\
\hline & $\beta$ & Std. Error & Beta & & \\
\hline (Constant) & 0.725 & 0.111 & & 6.517 & 0.000 \\
\hline Mobbing & 0.763 & 0.070 & 0.572 & 10.859 & 0.000 \\
\hline
\end{tabular}

Since the significance level was seen in the ANOVA analysis conducted to test whether mobbing in Table 8 affects the dependent variable or not, the model of the effect of mobbing on the intention to leave is significant. It has been determined that mobbing positively affects the intention to leave. Each 1-unit change in mobbing creates a $32 \%$ change in the intention of leaving the job. In the light of this information, H5 was supported.

\section{Results and evaluations}

It is a known fact that the COVID-19 outbreak has revealed the importance of supply chains in the globalized world even ware. During the epidemic period, it has been realized that all supply chain operations must function flawlessly to deliver cleaning, food, and health products as soon as possible. Since Turkey is a country with a high potential to become an international supply chain centre, COVID19 capable of managing outbreaks true, that having a structure that can adapt rapidly to the innovations brought the case to the appropriate action areas, and the crisis is vital. The COVID-19 outbreak has gradually disrupted road transportation, passenger and freight transport all over the world. It resulted in the suspension of production and commercial activities for a certain period, additional controls at border entry-exit, and working with a few personnel. This situation caused the vehicles to wait for long 
periods at the customs and experience transportation delays. While some countries were closing their border gates, on the other hand, logistics companies had to change routes with the epidemic spreading rapidly.

The purpose of this study is to study, during the COVID-19 pandemic in the process of occupational commitment of employees in enterprises operating in the road transportation sector in Turkey, exposure to mobbing to assess the situation and measure its impact on the intention to leave the job of the sectors. As a result of the study, it was found that highway transport workers during the COVID-19 pandemic period were exposed to mobbing at a low level. The results show that highway transport workers' intention to leave is low, and their tendency to continue their work is high. Moreover, it has been concluded that highway transport workers' continuity and normative occupational commitment levels are high, while emotional occupational commitment is low during the COVID-19 pandemic. Highway transport workers feel it is an obligation to stay in the logistics sector and consider continuing their profession as a responsibility that must be fulfilled. Also, they have a friendly relationship with their colleagues and are not exposed to threats and harassment much in logistics enterprises. It was determined that while mobbing did not negatively affect emotional occupational commitment, it negatively affected normative occupational commitment. Moreover, continuity and normative occupational commitment do not negatively affect the intention to leave. On the other hand, there is a positive and significant relationship between mobbing and the intention to leave.

It is imperative to protect highway workers responsible for the planning, organising and executing logistics operational processes with high work stress, race over time, and a complex structure. Support packages such as teleworking, short-time work allowance, unemployment insurance, and unemployment benefits have a feature that can affect employees' occupational commitment and their intention to leave. In this framework, taking actions to increase the motivation of highway transport workers and their inclusion in decision-making processes will strengthen their occupational commitment. Also, positive practices for highway transport workers will increase their job satisfaction, reduce their intention to leave, prevent them from shifting to competitors, and ultimately, a happy employee-happy customer climate will be achieved. It is necessary to strengthen the communication with highway workers during the pandemic period and consider the requests and needs of the employees. To ensure a healthy relationship in the road transportation sector, it is essential to clearly define the employees' duties and responsibilities and apply the performance system well. In addition to clearly stating highway employees' job descriptions, the senior management should provide control and autonomy for the functional regulation of power relations in the organizational hierarchy. Care should be taken to recruit employees in line with the dynamics of the sector in road transportation, and a fair rewarding system should be implemented effectively among employees. Also, legal measures should be taken to prevent mobbing in the road transportation sector, and mobbing victims should be legally protected.

The results obtained in our study support the literature. Power et al. (2013) and Law, Dollard, Tuckey, and Dormann (2011) argue that mobbing negatively affects occupational commitment. Einarsen, Skogstad, Rørvik, Lande and Nielsen, (2016) prove that the professional commitment of employees exposed to mobbing is reduced. Tak and Çiftçioğlu 2007) found that employees with high occupational commitment and who adopt organizational values have high job satisfaction and low intention to quit. Yildız (2018) study determined that mobbing has a full mediating effect between leader-member change and intention to leave.

On the other hand, Yapıcı Akar, Anafarta and Sarvan (2011) in Turkey in the work of the employees in the sample, more than half were exposed to mobbing, and they have low job satisfaction intention to leave argues that high. During the COVID-19 pandemic, businesses operating in the road transportation sector will adapt to digital transformation processes, gaining a competitive advantage internationally. In their studies, Pilikoğlu and Sağlam (2020) argue that with the COVID-19 outbreak, Logistics 4.0 applications (internet of things, big data, intelligent robots, artificial intelligence, 3D-4D printers, augmented reality, etc.) will function more effectively.

This study provides two main contributions to the literature. First, the effects of the COVID-19 pandemic on-road transportation were examined. Secondly, the impact of commitment and mobbing on the intention to leave in road transportation during the pandemic was analyzed. With the SEM (Structural Equation Model) method, future studies plan to measure and compare occupational commitment and intention to leave in maritime transport enterprises, effective in international trade during the COVID-19 pandemic, with the SEM (Structural Equation Model) method. 


\section{Peer-review:}

Externally peer-reviewed

\section{Conflict of interests:}

The author(s) has (have) no conflict of interest to declare.

\section{Grant Support:}

The author(s) declared that this study had received no financial support.

\section{Ethics Committee Approval:}

Ethics committee approval was received for this study from İstanbul Ticaret University, Ethics Committee on 24/03/2021 and E-65836846-044-205862 document number.

\section{Author Contributions:}

Idea/Concept/Design: G.Y. Data Collection and/or Processing: G.Y. Analysis and/or Interpretation: G.Y. Literature Review: G.Y., N.B. Writing the Article: G.Y., N.B. Critical Review: G.Y. Approval: G.Y.

\section{References}

Abdallaa, M.J., Said, H., Ali, L., Ali, F., Chen, X. (2021). COVID-19 and unpaid leave: Impacts of psychological contract breach on organizational distrust and turnover intention: Mediating role of emotional exhaustion, Tourism Management Perspectives, 39, 1-9.

Acar, Z., Çakmak, E. (2013). Depolama ve Depo Yönetimi, Nobel Yayıncılık, Ankara.

Akbal, H. (2020). COVID-19 pandemisinin sağlik tedarik zincirine kamçı etkisi, Kesit Akademi Dergisi, 6 (25), 181-192.

Akçaci, T., Çınarlıoğlu, S.M. (2020). Yeni koronavirüs (COVID-19) salgınının lojistik ve ticarete etkisi. Gaziantep University Journal of Social Sciences, Special issue, 447-456.

Allen, N.J., Meyer, J.P. (1990), The measurement and antecedents of affective, continuance, and normative commitment to the organization, Journal of Occupational Psychology, 63 (1): 1-18.

Allen, D.G., Weeks, K.P., Moffitt, K.R. (2005), Turnover intentions and voluntary turnover: the moderating roles of self-monitoring, locus of control, proactive personality and risk a version, Journal of Applied Psychology, 90 (5), 980-990.

Altunay, E., Oral, G., Yalçınkaya, M. (2014). Eğitim kurumlarında mobbing uygulamalarına ilişkin nitel bir araştırma. Sakarya University Journal of Education, 4(1), 62-80.

Arıkan Saltık, I., Avcı, U., Kaya, U. (2016). Mesleki bağlılık ve mesleği bırakma niyeti üzerinde etken faktörler olarak birey-meslek uyumu ve mesleğin sosyal statüsü: Turizm sektöründe görgül bir araştırma, Journal of Business Research - Turk 8(3):42-63.

Baysal, A.C., Paksoy, M. (1999). Mesleğe ve örgüte bağl1lı̆ı̆n çok yönlü incelenmesinde Meyer-Allen Modeli. İ.Ü.İşletme Fakültesi Dergisi, 28 (1), 7-15.

Blau, G. (2003). Testing for a four-dimensional structure of occupational commitment. Journal of Occupational and Organizational Psychology, 76, 469-488.

Browne, M. N., Smith, M. A. (2008). Mobbing in the workplace: the latest illustration of pervasive individualism in American law, Employee Rights and Employment Policy Journal, 12, 131-161.

Carson, K., Carson, P., Philips, J., Roe, C. (1996). A career entrenchment model: Theoretical development and empirical outcomes, Journal of Career Development, 22, 273-286.

Cho, S., Johanson, M. M., Guchait, P. (2009). Employees intent to leave: A comparison of determinants of intent to leave versus intent to stay, International Journal of Hospitality Management, 28 (3), 374-381.

Clarke, J. (2002). Maymuncuk: İ̧syerinde İletişim ve Politika. İstanbul: Mess. 
Cohen, A. (2000), The Relationship between commitment forms and work outcomes: a comparison of three models, Human Relations, 53(3): 387-418.

Cotton, J. L., Tuttle, J. M. (1986). Employee turnover: A meta-analysis and review with implications for research, Academy of Management Review, 11(1), 55-70.

Cunningham, J.B., MacGregor, J. (2000). Trust and the design of work complementary constructs in satisfaction and performance human relations, Human Relations, 53 (12), 1575-1591.

Davenport, N., Schwartz, R.D., Elliott, G.P. (2003) Mobbing: İsyerinde Duygusal Taciz.(Çev.: Osman Cem Önertoy), İstanbul, Sistem Yayıncillk.

Doğan, A. (2014). Karayolu yük taşımacılığı, Beta Yayıncılık, İstanbul.

Einarsen, S., Skogstad, A., Rørvik, E., Lande, A.B., Nielsen, M.B. (2018). Climate for conflict management, exposure to workplace bullying and work engagement: A Moderated Mediation Analysis. International Journal of Human Resource Management, 29 (3),549-70.

Elchardus, M., Smits, W. (2008). The vanishing flexible: Ambition, self-realization and flexibility in the career perspectives of young Belgian adults, Work, Employment and Society, 22 (2): 243-262.

Erdirençelebi, M., Filizöz, B. (2016). Mobbingin etik iklim ve çalışanların işten ayrılma niyeti üzerine etkileri, Selçuk Üniversitesi Sosyal Bilimler Enstitüsü Dergisi, 35, 127-139.

Feldman, D.C., Arnold, H.J. (1983). Managing Individual and Group Behavior in Organizations. New York: McGraw- Hill College.

Genç, E., Kaya, E. (2021). COVID-19 pandemi sürecindeki gümrük mevzuatı değişikliklerinin lojistik faaliyetlerine ve çalışanların iş motivasyonuna etkisi. Eurasian Journal of Researches in Social and Economics, 8(1), 161-175.

Goulet, L.R., Singh, P. (2002). Career commitment: A reexamination and external, personal and workrelated variables. Journal of Vocational Behavior, 52, 260-269.

Griffeth, R. W., Hom, P. W., Gaertner, S. (2000). A Meta-analysis of antecedents and correlates of employee turnover: Update, moderator tests, and research implications for the next millennium, Journal of Management, 26 (3), 463-488.

Gül, H., Oktay E., Gökçe, H. (2008). İş tatmini, stres, örgütsel bağlllık, işten ayrılma niyeti ve performans arasındaki ilişkiler: sağlık sektöründe bir uygulama, Uluslarası Hakemli Sosyal Bilimler E-Dergisi Akademik Bakı̧̧ Dergisi, 20, 1-11.

Harvey, P., Harris, K. J., Martinko, M. J. (2008). The mediated influence of hostile attributional style on turnover intentions, Journal of Business and Psychology, 22 (4), 333-343.

Hsiao, A., Auld, C., Ma, E. (2015). Perceived organizational diversity and employee behavior. International Journal of Hospitality Management, 48, 102-112.

Huff, L., Kelley, L. (2003), Levels of organizational trust in individualist versus collectivist societies: a seven-nation study, Organizational Science, 14, 1, 81-90.

Hughes, L. W., Avey, J. B., Nixon, D.R. (2010). Relationships between leadership and followers' quitting intentions and job search behaviors. Journal of Leadership \& Organizational Studies, 17(4), 351-362

ILO. (2021). COVID-19 Pandemic. 6 Mart 2021, https://www.ilo.org/wcmsp5/groups/public/--dgreports/---dcomm/documents/briefingnote/wcms_767028.pdf

Ivanov, D. (2020). Predicting the impacts of epidemic outbreaks on global supply chains: A simulationbased analysis on the coronavirus outbreak (COVID-19/SARS-CoV-2) case. Transportation Research Part E, 136, 101922.

Kanten P. (2014). İşyeri nezaketsizliğinin sosyal kaytarma davranışı ve işten ayrılma niyeti üzerindeki etkisinde duygusal tükenmenin aracılık rolü. Aksaray Üniversitesi İktisadi İdari Bilimler Dergisi, 6 (1), 11-26.

Karacan, S., Kaya, M. (2011). Lojistik faaliyetlerde maliyetleme, Umuttepe Yayınevi, Kocaeli.

Karasar, N. (1998). Bilimsel araştırma yöntemleri. Ankara: Nobel Yayın Dağıtım.

Karayolları Genel Müdürlüğü (2021). Ulaşım verileri.

https://www.kgm.gov.tr/Sayfalar/KGM/SiteTr/Istatistikler/TrafikveUlasim.aspx 
Karlı, H., Tanyaş, M. (2019). Pandemï durumunda tedarik zïncïrï rïsk yönetïmine ilişskïn öneriler. İstanbul Ticaret Üniversitesi Sosyal Bilimler Dergisi COVID-19 Sosyal Bilimler Özel Sayısı, 37, 174-190.)

Kaur, B., Mohindru, P.D. (2013). Antecedents of turnover intentions: A literature review. Global Journal of Management and Business Studies, 3(10), 1219-1230.

Koban, E., Yıldırır Keser, H. (2011). Dış Ticarette Lojistik, Ekin Yayınevi, Bursa.

Kudielka, B.M. (2004). Cortisol day profiles in victims of mobbing, Journal of Psychosomatic Research, 56, 149-150.

Lagerlund, M., Sharp, L., Lindqvist, R., Runesdotter, S., Tishelman, C., (2015). Intention to leave the workplace among nurses working with cancer patients in acute care hospitals in Sweden, European Journal of Oncology Nursing, 19, 629-637.

Laleoğlu, A., Özmete, E. (2013). Mobbing ölçeği: Geçerlik ve güvenirlik çalışması, Sosyal Politika Çalışmalar, 1(31), 9-31.

Law, R., Dollard, M. F., Tuckey, M. R., \& Dormann, C. (2011). Psychosocial safety climate as a lead indicator of workplace bullying and harassment, job resources, psychological health and employee engagement. Accident Analysis and Prevention, 43, 1782-1793.

Liu, W., Liang, Y., Bao, X., Qin, J., Lim, M.K. (2020). China's Logistics development trends in the post COVID-19 Era. International Journal of Logistics Research and Applications, 1-12.

Loske, D. (2020). The Impact of COVID-19 on transport volume and freight capacity dynamics: an empirical analysis in german food retail logistics. Transportation Research Interdisciplinary Perspectives, 6:1-6.

Meyer, J.P., Allen, N.J. ve Smith, C.A. (1993). Commitment to organizations and occupations: extensions and test of a three-component conceptualization. Journal Of Applied Psychology, 78, 538-551.

Meyer, J.P. Stanley, D.J., Herscovitch, L., Topolnytsky, L. (2002). Affective, continuance, and normative commitment to the organization: A Meta-Analysis of Antecedents, Correlates, and Consequences. Journal of Vocational Behavior, 61(1), 20-52.

Mogaji, E. (2020). Impact of COVID-19 on transportation in Lagos, Nigeria. Transportation Research Interdisciplinary Perspectives, 6, 1-7.

Morrow, P.C. (1993). The theory and measurement of work commitment. Greenwich, CT: JAI Press

Nakiboğlu, G. (2020). COVID-19 döneminde küresel tedarik zincirlerinde yaşananlar ve dönüşüm. Çă̆g Üniversitesi Sosyal Bilimler Dergisi, 17(2), 1-16.

Pilikoğlu, A., Sağlam, M., (2020). COVID-19 pandemi sürecinde ve endüstri 4.0 çerçevesinde tedarik zinciri uygulamalarının değerlendirilmesi: lojistik sektöründe bir uygulama, Journal of Current Research on Social Sciences, 10(4), 853-866.

Power, J.L., Brotheridge, C. M., Blenkinsopp, J., Bowes-Sperry, L., Bozionelos, N., Buzády, Z., Chuang, A., Drnevich, D., Garzon-Vico, A., Leighton, C., Madero, S. M., Mak, W. M., Mathew, R., Monserrat, S. I., Mujtaba, B. G., Olivas-Lujan, M. R., Polycroniou, P., Sprigg, C. A., Axtell, C., Holman, D., RuizGutiérrez, J. A., Nnedumm, A.U.O. (2013). Acceptability of workplace bullying: A comparative study on six continents. Journal of Business Research, 66(3), 374-380.

Rusbelt, C. A., Farrell, D., Rogers, G., Mainous, A. (1988). Impact of exchange variables on exit, voice, loyalty and neglect: an integrative model of responses to decline job satisfaction, Academy of Management Journal, 31(3), 599- 627.

Said, R.M., El-Shafei, D.A. (2021). Occupational stress, job satisfaction, and intent to leave: nurses working on front lines during COVID-19 pandemic in Zagazig City, Egypt, Environmental Science and Pollution Research, 28, 8791-8801.

Saladie, O., Bustamante, E., Gutierrez, A. (2020). COVID-19 lockdown and reduction of traffic accidents in Tarragona province. Spain. Transport. Res. Interdiscip. Perspect. 8.

Salin, D. (2001) Prevalence and Forms of Bullying among Business Professionals: A Comparison of Two Different Strategies for Measuring Bullying, European Journal of Work and Organizational Psychology, 10(4): 425-441.

Saruhan, Ş.C., Özdemirci, A. (2016). Bilim, Felsefe ve Metodoloji. 4. Press. İstanbul: Beta Press. 
Senir, G. (2021). COVID-19 salgınında insani yardım lojistiğinin ve tedarik zinciri yönetiminin önemi. Fiscaoeconomia, 5(1), 296-308.

Tak, B., Çiftçioğlu, B. A. (2007). Mesleki bağlllık ve çalışanları örgütte kalma niyeti arasındaki ilişkiyi incelemeye yönelik görgül bir çalışma. Ankara Üniversitesi Siyasal Bilgiler Fakültesi Dergisi, 63 (4), 155178.

Takase, M., Maude, P., Manias, E., (2005). Nurses' job dissatisfaction and turnover intention: methodological myths and an alternative approach. Nursing and Health Sciences, 7, 209-217.

Taşkın, E., Durmaz, Y. (2012). Lojistik Faaliyetler, Detay Yayıncılık, Ankara.

Teng, Chih-Ching. (2008). The effects of personality traits and attitudes on student uptake in hospitality employment. International Journal of Hospitality Management, 27, 76-86.

Tuna, M., Yerlitaş, M. (2014). Etik iklim, işe yabancılaşma ve örgütsel özdeşleşmenin işten ayrılma niyeti üzerindeki etkisi: Otel işletmelerinde bir araştırma. Anatolia: Turizm Araştırmaları Dergisi, Cilt 25 (1), $105-117$.

Uştu, H., Tümkaya, S. (2017). Sınıf öğretmenlerinin mesleki bağlılık, işten ayrılma niyeti ve bazı sosyodemografik özelliklerinin örgütsel bağlllı̆̆ı yordama düzeylerinin incelenmesi. Elementary Education Online, 16(3), 1262-1274.

Vandekerckhove, W., Commers, M.S. (2003). Downward workplace mobbing: A Sign of the Times? Journal of Business Ethics, 45,41-50.

Varol, F., Karaer, M., Ortakarpuz, M. (2017). İlaç mümessillerinin örgütsel bağlılığının, iş tatmininin ve işten ayrılma niyetinin demografik faktörler bağlamında incelenmesi. International Periodical for the Languages, Literature and History of Turkish or Turkic, 12(31), 279-302.

Vartia, M. (2001). Consequences of workplace bullying with respect to the well-being of tts targets and the observers of bullying. Scandinavian Journal of Work, Environment and Health, 27(1), 63-69.

Weisberg, J., Kirsschenbaum, A. (1991). Employee turnover intentions: Implications from a national sample. International Journal of Human Resource Management, 2(3), 359-375.

Wildes Vivienne J. (2004). Stigma in food service work: How it affects restaurant servers' intention to stay in the business or recommend a job to another, Tourism and Hospitality Research, 5(3), 213-233.

Yapıcı Akar, N., Anafarta, N., Sarvan, F. (2011). Causes, Dimensions and Organizational Consequences of Mobbing: An Empirical Study. Ege Akademik Bakis (Ege Academic Review) 11(1), 179-179.

Yildiz, S.M. (2018). An empirical analysis of the leader-member exchange and employee turnover intentions mediated by mobbing: Evidence from Sports Organisations. Economic Research-Ekonomska Istrazivanja 31(1), 480-97. 